\title{
An investigation into the curriculum ideology that foregrounds the presentation of HIV/AIDS content in selected South Africa Life Sciences textbooks
}

\author{
Lindelani Mnguni(i)
}

\begin{abstract}
Background: Research suggests that the South African school curriculum, including subjects such as Life Sciences, may be failing to address students' socio-scientific challenges such as HIV/AIDS. This could be due to the curriculum ideology that foregrounds content presented in the school subjects and related instructional designs. Given the increasing prevalence of HIV/AIDS among the youth, the present research sought to investigate the nature of

HIV/AIDS presented in the curriculum together with the curriculum ideologies that foreground this knowledge.

Methods: A mixed-methods approach was followed in line with the realism research paradigm. Inductive document analysis was performed on five purposively selected Life Sciences textbooks to determine curriculum ideologies that foreground the presentation of HIV/AIDS knowledge. A previously validated open-ended instrument was used to generate data, which were then analyzed inductively.

Results: Results show that HIV/AIDS knowledge is presented in the Life Sciences textbooks as stand-alone topics and as integrated concepts in other topics. This knowledge was found to be predominantly academic. Results in this instance show that HIV/AIDS content is foregrounded by the discipline-centered ideology rather than the student and citizenship-centered ideologies, which are better suited for social justice, citizenship education, and student and social accountability.
\end{abstract}

Conclusion: It is concluded that the Life Sciences will probably not lead to social empowerment of student concerning HIV/AIDS.

Keywords: Curriculum ideologies, HIV/AIDS education, Life Sciences, School curriculum

\section{Introduction to the research}

In light of the democratic dispensation in 1994, South Africa introduced a new school curriculum known as Curriculum 2005, which was aimed at cleansing content and pedagogy which were used by the apartheid government for oppression (Bantwini, 2010). This revised curriculum also attempted to introduce socio-political values that promote social justice through critical pedagogy (Waghid, 2005). However, poor infrastructure and

Correspondence: mngunle@unisa.ac.za

Department of Science \& Technology Education, College of Education, University of South Africa, 7-05 AJH van der Walt Building, UNISA, Pretoria, South Africa

inadequate teacher preparation led to the revision of this curriculum to introduce an outcomes-based curriculum known as the National Curriculum Statement (NCS) in 2002. In this revised curriculum, the primary intention was to streamline teaching and learning and to focus on outcomes rather than subject-specific content (Badat \& Sayed, 2014; Mnguni, 2013). However, several implementation challenges together with poor learner performance in national and international benchmark assessment led to the revision of the NCS to introduce the current Curriculum and Assessment Policy Statement (CAPS) (Badat \& Sayed, 2014; Mnguni, 2013). The CAPS curriculum attempts to balance the focus on 
outcomes as well as content with continued emphasis on citizenship education. However, there have already been calls for the revision of the current curriculum to bring about Africanization, contextualization, and decolonization. In this instance, scholars, societies, and students are calling for a context-specific curriculum which could prepare students for everyday social challenges, such as HIV (human immunodeficiency virus) and AIDS (acquired immunodeficiency syndrome). In light of this, there is a need to explore the extent to which the CAPS curriculum, textbooks, and teaching practices can foster contextualized citizenship education concerning democratic values. This, in turn, could lead to the development of a framework for measuring the success of the democratic educational reforms.

\section{Curriculum reform and its relevance}

Educational authorities around the world often institute curriculum reforms to deal with various national and international socio-economic and scientific challenges. For example, Hoeg and Bencze (2017) suggest that in the USA curriculum reforms were introduced to improve the global socio-scientific and economic competitiveness of the USA. Pietarinen, Pyhältö, and Soini (2017) posit that curriculum reform may also seek to translate and integrate emerging scientific discoveries into educational practices in the promotion of social equity Porter, Fusarelli, \& Fusarelli, 2015. However, in some instances, curriculum reform may be based on the need to transform educational philosophies and theories that underpin education, such as moving away from teacher-centered pedagogies to student-centered ones (Bulut, 2007). Therefore, curriculum reforms can be informed by political, pedagogical, and curriculo-philosophical imperatives.

While curriculum reform in South Africa has led to the adoption of the CAPS curriculum, poor student performance and the increase in the youth unemployment rate have led to various student protests locally known as \#FeesMustFall protests (Le Grange, 2016). Even though these protests are primarily driven by university students, secondary school students have also voiced the same concerns Luescher, Loader, \& Mugume, 2017. In particular, students are calling for a nation-wide curriculum reform that would ensure that basic and higher education curricula are decolonized and Africanised and that teaching, and learning are context-specific (Le Grange, 2016).

Bhana and Pillay (2018) note that the \#FeesMustFall protests were rooted in multiple social challenges that young people face, namely gender inequalities, sexual violence, and HIV/AIDS. A context-specific curriculum, therefore, should deal with these issues and empower young people with relevant skills and knowledge. For example, statistics show that the prevalence of HIV/AIDS in South Africa has steadily increased since 2002
(Statistics South Africa, 2018). Statistics South Africa (2018) reports that the prevalence of HIV in 2018 in South Africa was $13.06 \%$ compared to $10.74 \%$ in 2008 . They report that approximately $23 \%$ of South African women aged 15 to 49 are living with HIV. This high prevalence of HIV/AIDS among women is driven by illiteracy, gender inequalities, and sexual violence, among others. Chop et al. (2017) have also argued that socio-economic factors play a significant role in the spread and impact of HIV/ AIDS, particularly among women. These factors include unemployment, food insecurity, and illiteracy, which have also been associated with poor HIV/AIDS-related clinical outcomes. Other researchers have also suggested that cases of susceptibility to HIV/AIDS-related opportunistic infections and poor access to health care are higher among women (Chop et al., 2017). Statistics South Africa (2018) also estimates that 19\% of adults (aged 15-49) in South Africa are HIV positive.

The high prevalence of HIV/AIDS in sub-Saharan Africa suggests that the spread of HIV/AIDS may be affected by geopolitical factors. To this end, Kharsany and Karim (2016, p. 35) indicate that in 2016, "sub-Saharan Africa is home to only $12 \%$ of the global population, yet accounts for $71 \%$ of the global burden of HIV infection." Therefore, given these statistics, the present researcher argues that HIV/AIDS remains a concern for South Africa, which must be dealt with, among other means, through context-specific science education. It is for this reason that the role played by formal education through its curriculum must be investigated and improved where possible. For example, there is a dearth of knowledge on the extent to which the school textbooks present content knowledge that could empower learners to adopt safe behavioral practices to reduce the spread of HIV/AIDS.

\section{The significance of textbooks}

In the South African context, Life Sciences (previously known as Biology) is the only school subject where learners are taught the biology of HIV/AIDS. To this end, previous research has shown that learners may depend on scientific knowledge learned in Life Sciences to make decisions related to HIV/ AIDS (Mnguni \& Abrie, 2012). However, an analysis of the Life Sciences curriculum has shown that several concepts necessary for learners to understand the nature and characteristics of HIV/AIDS are not prescribed in the CAPS curriculum (Wolff \& Mnguni, 2015). It has also been found that the Life Sciences curriculum is designed in a manner that may not empower learners concerning HIV/AIDS. Mnguni (2013) argues that this could be because the CAPS curriculum adopts a curriculum ideology that does not foster learner and social empowerment. As a result, the concepts prescribed in the curriculum 
are not context-specific to the needs and challenges faced by learners.

In the continued exploration of the role of Life Sciences in the fight against HIV/AIDS, thorough textbook analysis remains to be carried out. This is because curriculum statements, which have been investigated extensively, tend to provide a framework of knowledge and skills that must be taught in a subject, while textbooks are primary vehicles for delivering content knowledge (Mohammed, 2007). Sharma and Buxton (2015, p. 262) also argue that "researchers need to investigate the preferred official representation of science in school (textbooks) so as to understand better how school science is shaped by broader socio-political forces." According to Knight (2015), textbooks assist teachers in integrating discipline knowledge and providing a framework on how teachers could foster the development of learning outcomes among students. Textbooks have also been shown to facilitate the development of cognitive skills, support knowledge construction, and information transfer (Knight, 2015). Scholars (e.g., Bazzul, 2015) also suggest that science textbooks could impact on social dynamics through the presentation of context-specific knowledge systems. While textbooks could broaden students' world view, research has shown that in some instances, textbooks could "limit the range of views students can legitimately hold" (Bazzul, 2015, p. 26). Additionally, science textbooks could also be used to inform and influence students' views on identity, ethnicity, and cultural diversity (Røthing \& Svendsen, 2011). Given their significance, as reported in other countries, the researcher sought to investigate the extent to which Life Sciences textbooks present HIV/AIDS knowledge.

\section{Theoretical framework}

Several factors inform the integration of content knowledge in textbooks. In the present research, Mnguni's (2018a, b) curriculum ideologies were used as a framework for exploring the extent to which the Life Sciences textbooks present HIV/AIDS knowledge. In classical sociology, ideology is defined as the comprehensive set of principles, values, and beliefs that a person or society holds which are reflected in their individual and collective thoughts and actions (Cole, 2019; Honderich, 2005; Van Dijk, 2006). In politics, an ideology defines how society ought to be organized and governed as well as the economic systems that must be put in place (Gee, 2008; Van Dijk, 2006). South Africa, for example, has transitioned from the colonial to the apartheid system and then to the current democratic system. While the colonial and apartheid systems have been banished, the recent \#FeesMustFall campaigns suggest that perhaps eradicating the intrinsic ideological principles, values, and beliefs from society is more intricate than previously thought. It is perhaps for this reason that educational authorities use the curriculum as a vehicle to gradually bring about social change. Within the education context, therefore, an ideology is defined as the underlying values of the curriculum as reflected on the overarching purpose of education, the characterization of the student and the teacher and their respective roles during teaching and learning and the nature, function, and purpose of knowledge, instructional process, and assessment (Schiro, 2013). Goodson (1990), therefore, suggests that at the center of a national curriculum and mass schooling is the intention to construct national polity, socialization, and national identity.

Mnguni (2018a, b) identifies four curriculum ideologies, namely discipline-centered ideology, service-centered ideology, student-centered ideology, and citizenship-centered ideology. Each of these ideologies is characterized within six facets of the curriculum, which are $(i)$ the purpose of the subject; (ii) the nature of knowledge; (iii) the instructional process (including teaching and learning); (iv) the role of the teachers; $(v)$ the role of the students and $(v i)$ the assessment (Schiro, 2013). The discipline-centered ideology seeks to transmit discipline-specific knowledge where the primary intention of teaching is to transmit the "epistemological and ontological principles of the discipline" (Mnguni, 2018b, p. 3101). This is aimed primarily at ensuring that the discipline maintains its identity and academic autonomy (Cotti \& Schiro, 2004; Schiro, 2013). The service-centered ideology focuses on teaching the essentialist form of knowledge and skills as a way of preparing students for their roles in service delivery for society (Schiro, 2013). The citizenship-centered ideology is informed by reconstructionist epistemology and ontology, where the foundational premise is that an "unhealthy" society can be transformed through an education that promotes reconstructionist views (Cotti \& Schiro, 2004). Therefore, education is aimed at providing students with the knowledge and skills required to identify, transform, and reconstruct social ills, norms, and values to enhance social empowerment (Kliebard, 2004). The student-centered ideology tends to prioritize students as the central component of teaching and learning where education is regarded as a way of supporting the student in developing his/her cognitive, affective, and psychomotor skills. The role of teachers in this regard is to nurture and facilitate the construction of knowledge and development of skills (Schiro, 2013). Based on the nature of each ideology, the student-centered and citizenship-centered ideologies are viewed as most suitable for a student and socially accountable curriculum (Mnguni, 2013).

Once a curriculum ideology has been identified, curriculum designers present content knowledge in various formats. For example, content can be presented in a subject-based format where each theme or topic is independent of another. Alternatively, an integrated format could be used where different topics and concepts are 
presented together to demonstrate the links between them Quintero et al., 2016. In this format, real-life case studies can be used. Furthermore, curriculum designers could make use of teacher-centered or student-centered methods. In health sciences, integrated student-centered approaches are mostly used since they allow for a holistic understanding of scientific phenomena.

\section{Aim of the present research}

The present research, therefore, sought to determine curriculum ideologies that foreground the presentation of HIV/AIDS knowledge in the Life Sciences textbooks as a proxy to determine the extent to which the curriculum supports student empowerment concerning HIV/AIDS. The research questions framing this research are as follows:

- How is HIV/AIDS knowledge presented in the Life Sciences textbooks?

- What is the nature of HIV/AIDS knowledge presented in the Life Sciences textbooks?

- Which curriculum ideologies foreground the presentation of HIV/AIDS knowledge in the Life Sciences textbooks?

\section{Methods}

In responding to the research questions, the researcher adopted a multiplistic realism research paradigm. Krauss (2005) suggests that realism, as a research paradigm, allows for flexible integration of the qualitative and quantitative research methods. This is done to enhance the validity and credibility of the findings. To this end, the researcher adopted the explorative mixed-method approach for data collection and analysis.

\section{Sampling and data collection}

The sources of data in the current research were five conveniently sampled Grade 11 Life Sciences textbooks. Life Sciences is a Further Education and Training (FET) Phase science subject in the South African curriculum for basic education, which is taught in the final three years of schooling (grades 10 to 12). This subject was purposively selected in the research because it is the only South African basic education subject where students learn biological content related to HIV/AIDS. The Department of Basic Education recommended the five textbooks analyzed in this research for use in schools. These are:

- Study E Master Life Sciences Gebhardt, Preethlall, Pillay, \& Farham, 2012

- Via Africa Life Sciences (Bowie et al., 2012)

- Solutions for All Life Sciences (McKay et al., 2012),

- Shuters Life Sciences Grade 11 Students Book (Ayerst et al., 2008), and,
- Focus on Life Sciences (Clitheroe et al., 2008).

These books were identified from a list of recommended textbooks provided by the Department of Basic Education and were acquired by the researcher for analysis.

\section{Data analysis}

The textbooks were analyzed inductively, using a validated document analysis instrument (modified from Mnguni (2013) and Wolff and Mnguni (2015)). This instrument was developed and validated for content, face, and criterion validity through a panel of experts, as recommended by Creswell (2008). The instrument was made up of open-ended items which were divided into three sections. The first section sought to determine how HIV/AIDS knowledge is presented in the textbooks. Specifically, the presentation of the following concepts was explored:

- Definition of HIV

- Characteristics of viruses

- Transmission of HIV

- HIV target cells

- Binding mechanism of HIV

- HIV entry into a host cell

- Replication of HIV

- Effects of HIV on the body

- Treatment of AIDS

- Prevention of HIV infection

- Abstinence

- The use of condoms to prevent infection

- Antiretroviral drugs

- Nutrition

- Faithfulness to one sexual partner

- Healthy lifestyle

The second section of the instrument sought to determine the nature of HIV/AIDS content presented in the textbooks. Specifically, the researcher sought to determine if the content was functional or academic. As suggested by Wolff and Mnguni (2015), functional knowledge includes knowledge that specifies practical actions that can be taken to prevent HIV infection and manage HIV/AIDS. For example, this knowledge could include teaching learners about abstinence, faithfulness to one sexual partner, and condomizing (Wolff \& Mnguni, 2015). Academic knowledge is scientific knowledge that seeks to provide learners with a scientific understanding of the nature and characteristics of HIV/ AIDS. The third section sought to determine the curriculum ideology that foregrounds the presentation of the HIV/AIDS concepts by determining the apparent (i) purpose of the teaching these concepts, (ii) the 
nature of HIV/AIDS knowledge, (iii) the instructional process for teaching and learning these concepts, (iv) the role of the teachers and students during teaching of these concepts, and (vi) the nature of assessment of these concepts (Schiro, 2013).

Document analysis in this regard meant the researcher analyses the textbooks inductively to identify verbatim and narrated extracts from the textbooks which best demonstrated the HIV/AIDS concepts and the curriculum ideologies that foreground these concepts. AtlasTi was used to identify these text extracts, using keyword search options.

\section{Justification of the methods}

Data could have been collected from various sources to respond to the research questions of the present research, including curriculum designers, teachers, and learners, through methods such as interviews and surveys. However, the current research deemed document analysis of the curriculum and textbooks most suitable, because unlike individual perceptions and experiences, these documents reflect envisaged learning outcomes, detailed content knowledge, and a comprehensive set of learning experiences and assessment methods to be adopted by all subscribing schools (Knight, 2015; Sharma \& Buxton, 2015; Mohammed, 2007). However, further studies could explore curriculum designers, teachers, and learners' perceptions and experiences to understand further the extent to which the curriculum supports student empowerment concerning HIV/AIDS.

\section{Results}

The integration of content knowledge related to HIV/AIDS in the textbooks

Life Sciences has four knowledge strands in which HIV/ AIDS-related content is taught. Results showed that HIV/AIDS content could be taught as an integrated topic in which it is discussed in another topic or as a stand-alone topic. It was also found that HIV/AIDS content is presented as research and assessment activities, as discussed below.

\section{HIV/AIDS content as an integrated topic}

The presentation of HIV/AIDS in the textbooks was found to focus on making connections for students, allowing them to engage different concepts in activities that are relevant and meaningful to real life. For example, Via Africa Life Sciences uses HIV/AIDS to explain how cultural and biodiversity are affected by diseases, such as HIV/AIDS (Fig. 1a). Similarly, when teaching about the basic structure of viruses, Solutions for All uses HIV to explain that viruses may have DNA or RNA surrounded by a protein capsule (Fig. 1b).

Similarities were also observed in the manner in which HIV/AIDS is integrated into the textbooks. For example, Solutions for All (McKay et al., 2012), Study \& Master and Solutions for All, integrated HIV/AIDS content in a specific set of topics, while Shuters Life Sciences and Focus on Life Sciences also integrated HIV/AIDS content in a specific set of topics (Table 1). It was also found that all textbooks used the study of viruses and diseasecausing microbes to present HIV/AIDS-related content.

A

4.4 IKS and sustainable use of the environment

Southern Africa has much cultural diversity and biodiversity - botanists estimate we have over 21800 Angiosperm species alone. All this is collected

into a rich indigenous knowledge systems (IKS). As an emerging economy, we face many challenges:

- unemployment

- lack of scientists, preventing us becoming a global player in the world economy

- poverty and issues regarding food security

- diseases and pandemics such as HIV/AIDS and TB

- lack of adequate state (western-medicine based) healthcare especially in rural areas.

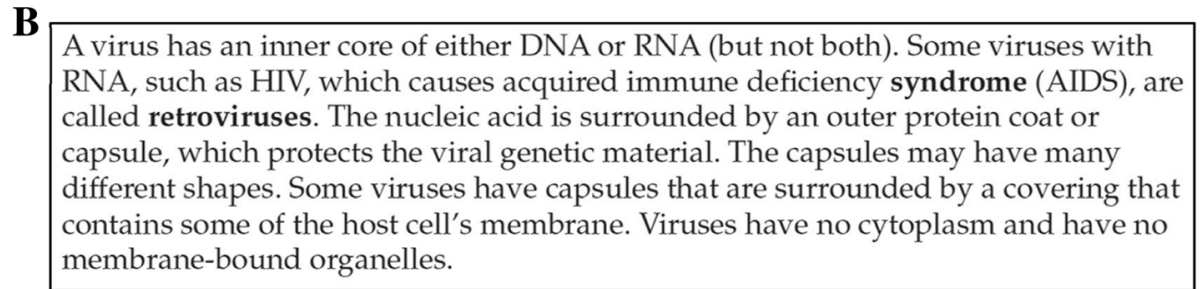

Fig. 1 a, b Extracts from Via Africa Life Sciences (Bowie et al., 2012, p. 280) and Solutions for All (McKay et al., 2012, p. 5) demonstrating how HIV/AIDS content is integrated into different topics 
Table 1 The integration of HIV/AIDS content in different topics in the Life Sciences textbooks

\begin{tabular}{|c|c|c|}
\hline Textbook & $\begin{array}{l}\text { Topic in which HIV/AIDS } \\
\text { content is integrated }\end{array}$ & Reference page \\
\hline \multirow[t]{5}{*}{$\begin{array}{l}\text { Study \& Master } \\
\text { Life Sciences }\end{array}$} & $\begin{array}{l}\text { Micro-organisms } \\
\text { and disease }\end{array}$ & $22,23,37,41,42$ \\
\hline & Immunology & $31,75,81$ \\
\hline & Nutrition & 182 \\
\hline & Respiratory diseases & 52,228 \\
\hline & Population dynamics & 307 \\
\hline \multirow{7}{*}{$\begin{array}{l}\text { Via Africa Life } \\
\text { Sciences }\end{array}$} & Microbes and disease & 22 \\
\hline & Immunology & 30,31 \\
\hline & Drugs and alcohol abuse & 149 \\
\hline & Respiratory diseases & 180 \\
\hline & Population dynamics & 217,241 \\
\hline & Nutrition & 271 \\
\hline & Biodiversity & 280 \\
\hline \multirow[t]{4}{*}{$\begin{array}{l}\text { Solutions for All } \\
\text { Life Sciences }\end{array}$} & $\begin{array}{l}\text { Biodiversity of } \\
\text { micro-organisms }\end{array}$ & 2 \\
\hline & Virology & 5 \\
\hline & $\begin{array}{l}\text { diseases caused by } \\
\text { micro-organisms }\end{array}$ & 18 \\
\hline & Respiratory diseases & 26 \\
\hline \multirow{7}{*}{$\begin{array}{l}\text { Shuters Life } \\
\text { Sciences }\end{array}$} & Viruses & $175-177$ and 189 \\
\hline & Bacteria & $180-182$ and $187-189$ \\
\hline & HIV/AIDS & 291 and 221 \\
\hline & TB & 188-189 \\
\hline & Immunity & $212-219$ \\
\hline & Circulatory system & $270-272$ and $275-290$ \\
\hline & Vaccination & $222-224$ \\
\hline \multirow{6}{*}{$\begin{array}{l}\text { Focus on Life } \\
\text { Sciences }\end{array}$} & Viruses & $78-83$ \\
\hline & Bacteria & $64-76$ \\
\hline & HIV/AIDS & $81-82$ and 161 \\
\hline & TB & 77 \\
\hline & Circulatory system & 139-160 \\
\hline & Vaccination & $84-85$ \\
\hline
\end{tabular}

\section{HIV/AIDS content as a stand-alone topic}

Of the books analyzed, Study \& Master was found to present most HIV/AIDS content as a stand-alone topic. For example, Study \& Master uses five pages (pages 41-45) to describe the basic characteristics of HIV, its replication cycle, signs and symptoms of infection, and the management and treatment of HIV/ AIDS. It also presents prevalence statistics from all the South African provinces. Learners are also given a research activity on HIV/AIDS. Shuters Life Sciences also presents HIV/AIDS as a stand-alone content as a follow-up to a section on the immune response. To this end, an insert is included in Shuters Life Sciences (p. 221), which provides a basic definition of HIV/ AIDS concerning immune response (Fig. 2).

\section{HIV/AIDS content as a research and assessment activity}

The textbooks also present HIV/AIDS content as a research activity which learners must carry out on their own. For example, Shuters Life Sciences has an activity that requires learners to research HIV/AIDS knowledge in the community (Fig. 3a). Via Africa Life Sciences, on the other hand, presents data and requires learners to interpret these data concerning the prevalence of HIV/AIDS and other diseases (Fig. 3b).

\section{The nature of HIV/AIDS knowledge in the textbooks}

Having established how HIV/AIDS knowledge is presented in the textbooks, the researcher investigated the nature of this knowledge. Results showed that both functional and academic knowledge were presented in the textbooks (Table 2). In particular, all the textbooks were found to present academic HIV/AIDS knowledge in great detail. However, there was variation in the presentation of functional knowledge. For example, only two textbooks, Study \& Master and Focus on Life Sciences, present knowledge related to the use of condoms to prevent HIV infection. Similarly, Study \& Master and Solutions for All were the only textbooks that discussed the use of antiretroviral drugs in the management of AIDS. Notably, abstinence and faithfulness to sexual partner as HIV infection prevention strategies received the least coverage, in the same way that healthy lifestyles as a means to manage AIDS also received the least coverage.

\section{Curriculum ideology that foregrounds the integration of HIV/AIDS knowledge in the textbooks}

Having established that academic and functional HIV/AIDS knowledge are both presented in the textbooks, the researcher went on to determine the curriculum ideology that foregrounds the presentation of HIV/AIDS knowledge. Data showed that the discipline-centered ideology was most dominant in all five textbooks (Table 2). This is primarily because the textbooks present academic knowledge the most. For example, all textbooks present academic HIV/AIDS knowledge as the already existing knowledge, which learners should master, which is typical of the discipline-centered ideology. This is also reflected in that the assessment tasks probe learners' understanding of this knowledge. For example, in Fig. 3b, learners are presented with "objective" statistical information and are asked to interpret it. This activity (Fig. 3b) could also be seen as reflecting a service-centered ideology where learners are expected to "perform tasks" of interpreting information. However, Fig. 3a represents an example of a classroom activity which is typical in student-centered and citizenship-centered ideologies. In these ideologies, 


\begin{abstract}
FOR YOUR INTEREST
HIV is a pathogen. HIV is called the Human Immunodeficiency Virus because it makes the immune system deficient. It has antigens that few people have antibodies to match. Therefore, our bodies cannot resist the infection if it reaches our tissues. HIV attacks the helper T-lymphocyte cells of our body and destroys them. This means that there are few helper cells to find the correct antibody for any other diseases that enter the body. Therefore, a person infected with HIV has little immunity to other infections and suffers from many diseases because the body cannot protect itself. When people suffer from these other diseases, we can say that they have AIDS (Acquired Immunodeficiency Syndrome). These other diseases will eventually kill the sufferer. You will find out more about HIV and AIDS in Unit 11.
\end{abstract}

Fig. 2 An extract depicting how HIV/AIDS content is presented in a Life Sciences textbook (extracted from Ayerst et al., (2008, p. 221))

knowledge is regarded as a subjective individuals' creative interpretation of their experiences and the society. In this activity (Fig. 3a), learners are tasked with collecting and interpreting information from the communities, as is typical in the student-centered and citizenship-centered ideologies. Based on these data, therefore, the researcher concludes that the four ideologies are reflected with varying emphasis with greater emphasis on the disciplinecentered ideology.

\section{Discussion}

In light of the high HIV/AIDS prevalence in South Africa, it is necessary to determine the role that is played by the formal curriculum to reduce the spread of HIV. To this end, the current research has found that HIV/ AIDS knowledge is presented in the Life Sciences textbooks as stand-alone topics, and it is also integrated into other topics as case studies and research activities. Quintero et al. (2016) suggest that integrating content in various topics increases students' interest in the topic and subject, which subsequently improves content understanding. Therefore, integrating HIV/AIDS knowledge into other topics and the use of case-based research activities could improve students' interest in learning about HIV/AIDS, which, in turn, could foster safe behavioral practices. Perhaps this could help alleviate the burden of HIV/AIDS, especially among the most vulnerable, such as women and children. Engaging learners in research activities in their local communities, as found in the present research, addresses concerns raised by Mnguni and Abrie (2012) in that HIV/AIDS knowledge can now be learned in the everyday context of the learners. This could, in turn, improve learners' ability to apply knowledge learned in school into their everyday lives (Chamany, Allen, \& Tanner, 2008; Holbrook, 2014). Further research is, however, required to determine the effectiveness of this context-based teaching method in reducing the spread of HIV/AIDS.
Previous research has shown that HIV/AIDS knowledge taught in school curricula does not always affect behaviors (Anderson \& Beutel, 2007). Mnguni and Abrie (2012) suggest that this is probably because such knowledge lacks depth and is presented in a manner that is not relevant to students. Other scholars also argue that HIV/AIDS knowledge is presented in the Life Sciences CAPS curriculum as academic knowledge rather than functional knowledge (e.g., Wolff \& Mnguni, 2015). The current research has, therefore, corroborated these observations in that Life Sciences textbooks also present HIV/AIDS knowledge mostly as academic knowledge. Viewed in isolation, this observation suggests that learners will probably not learn functional HIV/AIDS knowledge, which could lead to behavioral changes. This observation explains Mnguni, Abrie, and Ebersöhn's (2016) finding that non-biology and biology students report similar behavioral preferences, irrespective of their academic background. However, considering previous research, the present observation fails to explain why biology students have a significantly higher functional HIV/AIDS knowledge compared with non-biology students, as reported by Mnguni et al. (2016). Mnguni et al. (2016) found no correlation between the functional knowledge and behavioral preferences of students. Consequently, the role and significance of functional knowledge in affecting HIV/AIDS-related behaviors remain to be explored in detail.

What previous studies have not shown is the underlying reasons that foreground how HIV/AIDS knowledge is presented in the curriculum and textbooks. The present research has, however, shown that the student-centered and citizenship-centered ideologies are not the primary ideologies that foreground the integration of HIV/AIDS knowledge. Instead, it is the discipline-centered ideology that foregrounds this content even though other ideologies were reflected in the HIV/AIDS-related content knowledge. As implied by Mnguni (2018a) and Schiro (2013), 
A

In this activity, you will find out what people in your community know about HIV/AIDS.

In a group, plan your survey.

1. Decide how many people each of your will interview.

2. Decide how you will record the information you will be collecting.

3. Decide what questions you will ask. For example, you could ask the following questions:

- What does HIV mean?

- What is HIV?

- What does HIV do to a person's body?

- What does AIDS mean?

- What happens when a person has AIDS?

- Do you think that HIV/AIDS is a problem in South Africa?

- DO you think that the South African government should do more about the HIV/AIDS problem?

- What should the government do about this problem?

4. You should use some of your own questions as well.

Note: Be sensitive to the fact that some people may not want to talk about HIV/AIDS. Some people may not believe that these diseases exist. Other people may not want to acknowledge that people they know have died from HIV/AIDS.

5. Combine all the information that your group has recorded. You can also use the information you collected in Activity 11.

6. Then you each write an article for a newspaper that describes your research and findings on people's knowledge of HIV/AIDS in your community.

7. Hand in your article.

8. When your teacher has marked it, display it in the classroom. If your school produces a school newspaper, your teacher may choose an article to be published.

\section{B Activity 2 What are the deadliest infectious diseases?}

Aim

Analysing and interpreting data on infectious diseases

What you do

Use the bar graph to draw a pie chart of the six most common infectious diseases that cause death in Africa.

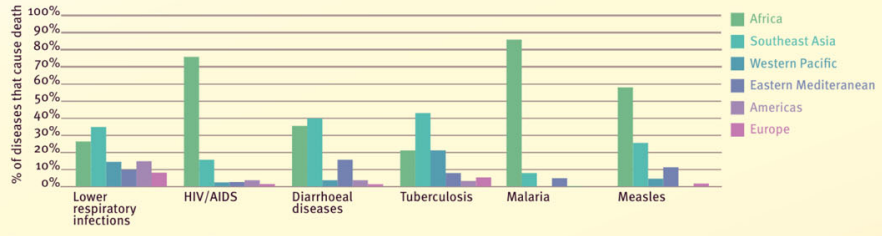

The six most common infectious diseases that cause death

Questions

1 What conclusions can you reach when you compare the data on HIV/AIDS and TB from Africa and South East Asia?

2 Which are the two most problematic diseases in Africa?

3 Explain how government can prevent the spread of TB and prevent people from contracting it again. (6)

Fig. 3 a, b Research activities which learners are expected to do (extracted from Ayerst et al., 2008, p. 292; and, Bowie et al., 2012, p. 23)

the discipline-centered ideology is not concerned about the students or society's interests. Instead, it focuses on the preservation of the discipline and its ontology and epistemology. It is for this reason that Hodson (2004, p. 2) posits the following:

"Regrettably, science is often regarded as a body of knowledge that can be transmitted by teachers, memorized by students, and reproduced on demand in examinations. Regrettably, too, science is often portrayed as the de-personalized and disinterested pursuit of objective truth, independent of the society in which it is practiced and untouched by ordinary human emotions, values, and conventions".

In line with these views, the present researcher believes that the integration of HIV/AIDS content knowledge that is informed by the discipline-centered ideology will probably not lead to learner and social empowerment which could reduce the spread of HIV/AIDS. This analysis is supported by the fact that, while HIV/AIDS content has been integrated into the South African school curriculum, the prevalence has continued to increase steadily (Statistics South Africa, 2018); and science learners share the 
Table 2 Curriculum ideology that foreground HIV/AIDS knowledge presented in the Life Sciences textbooks

\begin{tabular}{|c|c|c|c|c|c|c|}
\hline $\begin{array}{l}\text { Nature of HIV/AIDS } \\
\text { knowledge }\end{array}$ & HIV/AIDS topics & Study \& Master & Via Africa & Solutions for All & $\begin{array}{l}\text { Shuters Life } \\
\text { Sciences }\end{array}$ & $\begin{array}{l}\text { Focus on Life } \\
\text { Sciences }\end{array}$ \\
\hline \multirow[t]{9}{*}{ Academic HIV/AIDS knowledge } & Definition of HIV & $x^{a}$ & $x^{a}$ & $x^{a}$ & $x^{a}$ & $x^{a}$ \\
\hline & Characteristics of viruses & $x^{a}$ & $x^{a}$ & $x^{a}$ & $x^{a}$ & $x^{a}$ \\
\hline & Transmission of HIV & $x^{a}$ & $x^{a}$ & $x^{a}$ & $x^{a}$ & $x^{a}$ \\
\hline & HIV target cells & $x^{a}$ & $x^{a}$ & $x^{a}$ & $x^{a}$ & $x^{a}$ \\
\hline & Binding mechanism of HIV & $x^{a}$ & $x^{a}$ & $x^{a}$ & $x^{a}$ & $x^{a}$ \\
\hline & HIV entry into a host cell & $x^{a}$ & $x^{a}$ & $x^{a}$ & $x^{a}$ & $x^{a}$ \\
\hline & Replication of HIV & $x^{a}$ & $x^{a}$ & $x^{a}$ & $x^{a}$ & $x^{a}$ \\
\hline & Effects of HIV on the body & $x^{a}$ & $x^{a}$ & $x^{a}$ & $x^{a}$ & $x^{a}$ \\
\hline & Treatment of AIDS & $x^{a}$ & & $x^{a}$ & $x^{a}$ & $x^{a}$ \\
\hline \multirow[t]{7}{*}{ Functional HIV/AIDS knowledge } & Prevention of HIV infection & $x^{a, b}$ & $x^{a, b}$ & $x^{a, b}$ & $x^{a, b}$ & $x^{a, b}$ \\
\hline & Abstinence & & & & & \\
\hline & Condomising & $x^{b, c}$ & & & & $x^{b, c}$ \\
\hline & Retroviral drugs & $X^{a, d}$ & & $X^{a, d}$ & & \\
\hline & Nutrition & $X^{a, b, c, d}$ & $X^{a, b, c, d}$ & & $X^{a, b, c, d}$ & $X^{a, b, c, d}$ \\
\hline & Faithfulness to sexual one partner & & & $X^{a, b, c, d}$ & & \\
\hline & Healthy lifestyle & & $X^{a, b, c, d}$ & & & \\
\hline
\end{tabular}

Discipline-centered ideology

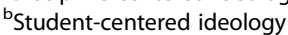

${ }^{c}$ Citizenship-centered ideology

${ }^{\mathrm{d}}$ Service-centered ideology

same risk behaviors as non-science learners (Mnguni et al., 2016).

The findings of the current study also support previous research, which has shown that Life Sciences as a subject is not foregrounded by single-curriculum ideology Mnguni, 2018a, 2013. Researchers suggest that this mélange of ideologies is to be expected as curricula tend to adopt overlapping curriculum ideologies (Kliebard, 2004; Mnguni, 2013). Mnguni (2018a, b), however, notes that the Life Sciences reflect the citizenship-centered ideology the least. This is despite suggestions that citizenship-centered ideology is best suited for social reconstruction and empowerment (Schiro, 2013). Literature shows that citizenship-centered ideology does not focus only on the intellectual development of students. Instead, it also integrates scientific knowledge into the social, moral context of students, something which the \#FeesMustFall students called for in that they argued for a decolonized context-specific curriculum that fosters social empowerment (Le Grange, 2016). In such a "decolonized context-specific curriculum" informed by citizenship-centered ideology, the everyday experiences of the student and the teacher are valued equally with the scientific knowledge written in the textbook and all together used to understand, deconstruct, and reconstruct social norms for the betterment of society. It is against this background that the present researcher argues that by adopting the discipline-centered ideology as its primary vehicle, Life Sciences will probably not lead to social empowerment concerning HIV/AIDS.

\section{Conclusion}

Ultimately, the Life Sciences textbooks present relevant and significant HIV/AIDS knowledge in line with the democratic government's objectives as recommended by Chi, Feltovich, and Glaser (1981), Fraser (1993), and Veness (2010). However, the underlying curriculum ideology does not seem to support student empowerment. The researcher, therefore, concludes that the adoption of all four curriculum ideologies with greater emphasis on the discipline-centered ideology to foreground the integration of HIV/AIDSrelated content knowledge may not be suitable for the needs of students and the society. The researcher also argues that, in line with the social empowerment and citizenship and aspiration of the CAPS curriculum, greater emphasis should be placed on the studentcentered and citizenship-centered ideologies. This should be done within context-specific themes such as HIV/AIDS which have a significant impact on the students and the society. This way, the demands of an Africanised, contextualised, and decolonized curriculum could be realized. The researcher, however, notes that Life Sciences may not be the school 
subject that seeks to promote safe behavioral practices. As such, the findings of the present research may be limited. Further research is therefore required to explore curriculum ideologies that foreground other school subjects, in other socio-scientific contexts, which may be affecting South African learners.

\section{Abbreviations}

AIDS: Acquired immunodeficiency syndrome; CAPS: Curriculum and Assessment Policy Statement; HIV: Human immunodeficiency virus; NCS: National Curriculum Statement

\section{Acknowledgements}

The researcher would like to thank the National Research Foundation for funding the study. Colleagues who participated in the panel of experts are also acknowledged.

\section{Authors' contributions}

The author conceptualized the research, collected and analyzed the data, and wrote the manuscript. The author read and approved the final manuscript.

\section{Funding}

This research was funded by the South African National Research Foundation (NRF) (GUN 99210).

\section{Availability of data and materials}

At the time of this research, the textbooks used in this research were available in bookstores in South Africa.

\section{Ethics approval and consent to participate}

This research was granted Ethical Clearance by the University of South Africa (reference number 2018/03/14/90291786/28/MC), which includes permission to publish the results of the research, as reported in this article.

\section{Consent for publication}

Not applicable, the manuscript does not contain any person's data in any form.

\section{Competing interests}

The author does not have any competing interests to report.

Received: 9 November 2018 Accepted: 26 June 2019

Published online: 11 July 2019

\section{References}

Anderson, K. G., \& Beutel, A. M. (2007). HIV/AIDS prevention knowledge among youth in Cape Town, South Africa. Journal of Social Sciences, 3(3), 143-151.

Ayerst, P., Langley, R., Majozi, P., Metherell, A., Raciborska, C., \& Smith, D. (2008). Shuters Life Sciences Grade 11 Learners Book. Cape Town: Shuter \& Shooter Publishers.

Badat, S., \& Sayed, Y. (2014). Post-1994 South African education: The challenge of social justice. The ANNALS of the American Academy of Political and Social Science, 652(1), 127-148. https://doi.org/10.1177/0002716213511188.

Bantwini, B. D. (2010). How teachers perceive the new curriculum reform, Lessons from a school district in the Eastern Cape Province, South Africa. International Journal of Educational Development, 30(1), 83-90. https://doi.org/10.1016/j. ijedudev.2009.06.002

Bazzul, J. (2015). Tracing "ethical subjectivities" in science education: How biology textbooks can frame ethico-political choices for students. Research in Science Education, 45(1), 23-40. https://doi.org/10.1007/s11165-014-9411-4.

Bhana, D., \& Pillay, J. (2018). Negotiating femininities on campus: Sexuality, gender, and risk in an HIV environment. Health Education Journal, 77(8), 915926. https://doi.org/10.1177/0017896918784693.

Bowie, M., de Beer, J., Johannes, A., Mhlongo, R., Pretorius, R., \& Whitlock, E. (2012). Via Africa Life Sciences. Cape Town: Via Africa.

Bulut, M. (2007). Curriculum reform in Turkey: A case of primary school mathematics curriculum. Eurasia Journal of Mathematics, Science \& Technology Education, 3(3), 203-212. https://doi.org/10.12973/ejmste/75399.
Chamany, K., Allen, D., \& Tanner, K. (2008). Making biology learning relevant to students: integrating people, history, and context into college biology teaching. CBE-Life Sciences Education, 7(3), 267-278. https://doi.org/10.1187/ cbe.08-06-0029.

Chi, M. T. H., Feltovich, P. J., \& Glaser, R. (1981). Categorization and representation of physics problems by experts and novices. Cognitive Science, 5(2), 121-152

Chop, E., Duggaraju, A., Malley, A., Burke, V., Caldas, S., Yeh, P. T., et al. (2017). Health care for women international food insecurity, sexual risk behavior, and adherence to antiretroviral therapy among women living with HIV: A systematic review. Health Care for Women International, 38(9), 927-944. https://doi.org/10.1080/07399332.2017.1337774

Clitheroe, F., Doidge, M., Marsden, S., van Aarde, I., Ashwell, A., Buckley, L., \& Dilley, L. (2008). Focus on Life Sciences. Cape Town: Maskew Miller Longman

Cole, N. L. (2019). Theories of Ideology. Retrieved from https://www.thoughtco. com/ideology-definition-3026356.

Cotti, R., \& Schiro, M. (2004). Connecting teacher beliefs to the use of children's literature in teaching of mathematics. Journal of Mathematics Teacher Education, 7, 329-356. https://doi.org/10.1007/s10857-004-1787-z.

Creswell, J. W. (2008). Educational Research, planning, conducting, and evaluating quantitative and qualitative research (3rd ed.). Boston: Pearson Education International.

Fraser, W. J. (1993). The selection and ordering (arrangement) of learning content. In W. J. Fraser, C. P. Loubser, \& M. P. van Rooyen (Eds.), Didactics for the undergraduate student (2nd ed.). Durban: Butterworths.

Gebhardt, A., Preethlall, P., Pillay, S., \& Farham, B. (2012). Study \& Master Life Sciences. Cape Town: Cambridge University Press.

Gee, J. P. (2008). Social Linguistics and Literacies: Ideology in Discourse (3rd ed.) London and New York: Routledge.

Goodson, I. E. (1990). Nations at risk and national curriculum: Ideology and identity. Journal of Education Policy, 5(5), 219-232. https://doi.org/10.1080/026 80939008549073

Hodson, D. (2004). Going Beyond STS: Towards a curriculum for socio-political action. The Science Education Review, 3(1), 1-6.

Hoeg, D. G., \& Bencze, J. L. (2017). Values underpinning STEM Education in the USA: An analysis of the next generation science standards. Science Education, 101(2), 278-301. https://doi.org/10.1002/sce.21260.

Holbrook, J. (2014). A context-based approach to science teaching. Journal of Baltic Science Education, 13(2), 1648-3898.

Honderich, T. (2005). The Oxford Companion to Philosophy. Oxford: OUP.

Kharsany, A. B., \& Karim, Q. A. (2016). HIV infection and AIDS in sub-Saharan Africa: current status, challenges, and opportunities. The Open AIDS Journal, 10, 34-48. https://doi.org/10.2174/1874613601610010034.

Kliebard, H. M. (2004). The struggle for the American curriculum, 1893-1958 (3rd ed. ). New York: Routledge.

Knight, B. A. (2015). Teachers' use of textbooks in the digital age. Cogent Education, 2(1), 1015812. https://doi.org/10.1080/2331186X.2015.1015812.

Krauss, S. E. (2005). Research paradigms and meaning-making: A primer. The Qualitative Report, 10(4), 758-770.

Le Grange, L. (2016). Decolonizing the university curriculum. South African Journal of Higher Education, 30(2), 1-12. https://doi.org/10.20853/30-2-709.

Luescher, T., Loader, L., \& Mugume, T. (2017). \#FeesMustFall: An Internet-age student movement in South Africa and the case of the University of the Free State. Politikon: South African Journal of Political Studies, 44(2), 231-245. https://doi.org/10.1080/02589346.2016.1238644.

McKay, I., Webb, J., Marchant, L., Freedman, R., Simenson, R., de Fontaine, J., \& van der Merwe, C. D. (2012). Solutions for All Life Sciences. Northlands: MacMillan South Africa.

Mnguni, L. (2013). The curriculum ideology of the South African secondary school Biology. South African Journal of Education, 33(2), 1-11.

Mnguni, L. (2018a). Citizenship education and the curriculum ideologies of Natural Sciences and Life Sciences curricula in South Africa. Curriculum Perspectives, 38(2), 97-106. https://doi.org/10.1007/s41297-018-0044-z.

Mnguni, L. (2018b). The curriculum ideology recommended by novice teachers for life sciences in South Africa. EURASIA Journal of Mathematics, Science and Technology Education, 14(7), 3099-3108. https://doi.org/10.29333/ejmste/91663.

Mnguni, L., \& Abrie, M. (2012). HIV/AIDS content knowledge and presentation strategies in biology for effective use in everyday life. Journal of Biological Education, 46(4), 226-233. https://doi.org/10.1080/ 00219266.2012 .716778 
Mnguni, L., Abrie, M., \& Ebersöhn, L. (2016). The relationship between scientific knowledge and behavior: an HIV/AIDS case. Journal of Biological Education, 50(2), 147-159. https://doi.org/10.1080/00219266.2015.1007888.

Mohammed, A. (2007). Challenging HIV/AIDS Stigma and discrimination among students by incorporating HIV/AIDS into the curriculum. Paper presented at the Imagined Futures II: universities as incubators of change, University of Pretoria. Pretoria: Centre for the Study of AIDS.

Pietarinen, J., Pyhältö, K., \& Soini, T. (2017). Large-scale curriculum reform in Finland-exploring the interrelation between implementation strategy, the function of the reform, and curriculum coherence. The Curriculum Journal, 28(1), 22-40. https://doi.org/10.1080/09585176.2016.1179205.

Porter, R. E., Fusarelli, L. D., \& Fusarelli, B. C. (2015). Implementing the common core: How educators interpret curriculum reform. Educational Policy, 29(1), 111-139. https://doi.org/10.1177/0895904814559248.

Quintero, G. A., Vergel, J., Arredondo, M., Ariza, M. C., Gómez, P., \& Pinzon-Barrios, A. M. (2016). Integrated medical curriculum: advantages and disadvantages. Journal of Medical Education and Curricular Development, 3, 133-137. https:// doi.org/10.4137/JMecd.S18920

Røthing, À., \& Svendsen, S. H. B. (2011). Sexuality in Norwegian textbooks: constructing and controlling ethnic borders? Ethnic and Racial Studies, 34(11), 1953-1973. https://doi.org/10.1080/01419870.2011.560275.

Schiro, M. S. (2013). Curriculum theory: Conflicting visions and enduring concerns (2nd ed.). London: Sage.

Sharma, A., \& Buxton, C. A. (2015). Human-nature relationships in school science: A critical discourse analysis of a middle-grade science textbook. Science Education, 99(2), 260-281. https://doi.org/10.1002/sce.21147.

Statistics South Africa. (2018). Mid-year population estimates. Pretoria: Stats SA Retrieved from https://www.statssa.gov.za/publications/P0302/P03022018.pdf.

Van Dijk, T. A. (2006). Politics, ideology, and discourse. In K. Brown (Ed.), The Encyclopedia of language, and linguistics (2nd ed., pp. 728-740). New York: Pergamon Press. https://doi.org/10.1016/B0-08-044854-2/00722-7.

Veness, D. (2010). "As simple as possible": the bones of curriculum design. In C. H. Steel, M. J. Keppell, P. Gerbic, \& S. Housego (Eds.), Curriculum, technology \& transformation for an unknown future. Proceedings ascilite Sydney 2010 (pp. 1002-1006) Retrieved from http://ascilite.org.au/conferences/sydney10/procs/ Veness-concise.pdf.

Waghid, Y. (2005). Action as an educational virtue: toward a different understanding of democratic citizenship education. Educational Theory, 55(3), 323-342. https://doi.org/10.1111/j.1741-5446.2005.00006.x.

Wolff, E., \& Mnguni, L. (2015). The integration of HIV and AIDS as a socio-scientific issue in the life sciences curriculum. African Journal of Research in Mathematics, Science and Technology Education, 19(3), 213-224.

\section{Publisher's Note}

Springer Nature remains neutral with regard to jurisdictional claims in published maps and institutional affiliations.

\section{Submit your manuscript to a SpringerOpen ${ }^{\circ}$ journal and benefit from:}

- Convenient online submission

- Rigorous peer review

- Open access: articles freely available online

- High visibility within the field

- Retaining the copyright to your article

Submit your next manuscript at $\boldsymbol{\nabla}$ springeropen.com 